RESEARCH ARTICLE

\title{
Diversity of butterflies in different habitat types of Seethawaka wet zone botanic gardens and Indikadamukalana forest reserve of Sri Lanka
}

\author{
M.U.H. Peiris ${ }^{1}$, C.D. Dangalle ${ }^{1, *}$, N. Pallewatta ${ }^{1}$ and S. Wijesundara ${ }^{2}$ \\ ${ }^{1}$ Department of Zoology and Environment Sciences, Faculty of Science, University of Colombo, Colombo, Sri Lanka. \\ ${ }^{2}$ National Institute of Fundamental Studies, Kandy, Sri Lanka.
}

Received: 01/07/2019 ; Accepted: 25/01/2020

\begin{abstract}
Botanic gardens, forest reserves and other protected areas are established to conserve biodiversity. The present study was conducted to assess the butterfly diversity in a recently established botanic garden of Sri Lanka, the Seethawaka Wet Zone Botanic Gardens (SWZBG) and Indikadamukalana Forest Reserve (IMFR) adjacent to the garden. Three different habitat types within the botanic gardens, the undisturbed forest habitat within the forest reserve and the buffer zone between the Botanic Gardens and Forest Reserve were investigated for butterflies. Butterfly species richness, diversity, endemic species, family composition in different habitats and effects of habitat parameters on butterfly distribution were assessed. Butterflies were collected from five habitats - grassland, shrub, disturbed forest, undisturbed forest, buffer zone, of the SWZBG and IMFR using transect line method with hand netting and fruit baited traps. Collected butterflies were identified using published field guides. Climate and soil parameters of each habitat were measured using standard methods and equipment. Differences of habitat parameters between habitats were estimated using OneWay Analysis of Variance and Tukey's Multiple Comparison method and butterfly diversity and evenness in different habitat types were assessed using Shannon-Weiner diversity index. The study revealed seventy-nine butterfly species from SWZBG and IMFR highlighting the importance of the sites for safeguarding and conservation of butterflies. Species richness and diversity of butterflies was highest in the buffer zone and lowest in the grassland habitat. The most common butterfly family in the study sites was family Nymphalidae. Endemic species were high in the forest habitat types. Significant differences were evident in habitat parameters between habitat types indicating their effect on butterfly species richness and diversity. The study revealed SWZBG and IMFR as important areas for butterfly occurrence when compared with similar botanic gardens and forest reserves elsewhere in the world.
\end{abstract}

Keywords: Buffer zone, Grassland habitat, Nymphalidae, Habitat parameters, Endemic butterflies.

\section{INTRODUCTION}

Butterflies are a taxonomically well studied group within the Lepidoptera and has received considerable attention throughout the world (Ghazoul, 2002) and are represented by17,280 species of which roughly two-thirds live in the tropics (Shields, 1989).

Sri Lanka is home to 247 species of butterflies including 31 endemic species and 84 endemic sub-species (van der Poorten and van der Poorten, 2016). Comprehensive publications on the butterfly fauna of Sri Lanka by Woodhouse (1949), d'Abrera (1998), and more recently by van der Poorten and van der Poorten (2016) provides valuable information on the identification, distribution, biology and food plants of individual species.

Several studies have documented the species composition of butterflies in different localities of Sri Lanka. Biodiversity surveys carried out by IUCN Sri Lanka have recorded butterfly species in Bundala National Park (Bambaradeniya et al., 2001) Muthurajawela Sanctuary (Bambaradeniya et al., 2002a), Maduganga Mangrove Estuary (Bambaradeniya et al., 2002b), Sinharaja Rain Forest (Bambaradeniya et al., 2003) and Anawilundawa Sanctuary (Perera et al., 2005). The butterfly fauna of Udawalawa National Park has been documented by Samarasinghe et al., 1998, and that of Tantirimale Archaeological site, Anuradhapura by Asela et al., 2009. Eventhough the occurrence of butterfly species in different areas of the island have been relatively well documented very little attention has been paid to the study of butterfly ecology prior to the work of van der Poorten and van der Poorten (2016).

The association between different habitat types of a tropical rain forest with diversity of butterfly communities has been demonstrated by $\mathrm{Vu}$ and $\mathrm{Vu}$ (2011) and according to Vu et al., 2015 habitat variation and disturbances within forests can affect butterfly communities and diversity in complex ways. Studies in Uganda revealed that forest remnants and semi-natural habitats are important for conservation of butterflies (Munyuli, 2013). Habitat type affected butterfly species richness and diversity indices in Bumbuna forest, Northern Sierra Leone and were lower in the disturbed habitats compared to the forest reserve (Sundufu and Dumbuya, 2008). However, contradictory observations have been revealed between butterflies and habitat types of Aokigahara primary woodland of Mount 
Fiji, Central Japan where butterfly species occurring in disturbed habitats were more voltine and had a wider host plant range (Kitahara, 2004).

Climatic and soil data of habitats are important in determining the distribution, diversity and abundance of butterflies and many studies elsewhere in the world have demonstrated this observation. Species richness of butterflies were found to be closely correlated with air temperature in lowland tropical forests of Bolivia, South America and species numbers differed significantly between seasons (Abrahamczyk et al., 2011). The range and occupancy of the monarch butterfly (Danaus plexippus plexippus) of the United States were determined using climate variables which affected host plants of the area (Dilts et al., 2019). Potential evapotranspiration measured in $\mathrm{mm} /$ year was a strong predictor of butterfly species richness in extensive terrestrial areas of Canada (Kerr, 2001). Soil type, soil moisture and soil acidity in agricultural landscapes of Iowa, USA were known to affect crop diversity and density which in turn influenced butterfly assemblages (Myers et al., 2015).

In Sri Lanka, Nisviya and Wickramasinghe (2012) revealed that the Northern flank of Knuckles Mountain holds a rich and unique butterfly assemblage and that this maybe due to the plant species with nectar bearing flowers in the area. Larval food plants of butterflies have been documented by Jayasinghe et al., 2014. Investigations in different habitat types of Wasgamuwa National Park, Sri Lanka have revealed that butterfly abundance and richness is lowest in primary forests when compared with secondary forests, wetland margins, shrubland and home gardens and species tend to be more specialized to the habitat they occupy (Slater et al., 2019). The diversity of butterflies in different habitat types in Matara have been recorded by Pathiraja et al. (2017). However, the diversity of butterfly species in different habitat types of Sri Lanka and their associations with specific habitat character traits have not been studied in detail. Therefore, the present study was conducted to investigate and record the butterfly fauna of an important and recently established biodiversity park, Seethawaka Wet Zone Botanic Gardens and a wet zone tropical forest, Indikadamukalana Forest Reserve of Sri Lanka. Different habitat types within the locations were surveyed and species richness associated with habitat parameters was determined.

\section{MATERIALS AND METHODS}

\section{Study Area}

The study was conducted in two locations: Seethawaka Wet Zone Botanic Gardens and the adjacent Indikadamukalana Forest Reserve $\left(6^{\circ} 57^{\prime} 11^{\prime} \mathrm{N}, 80^{\circ} 13^{\prime} 06^{\prime} \mathrm{E}\right)$, located in Labugama, Colombo District, Western Province of Sri Lanka (Figure 1).

Three habitat types were selected for the study within the Botanic Gardens as follows:

a. Grassland: The grassland habitat consisted mainly of perennial grasses dominated by the species Axonopus compressus and small herbaceous plants such as Zinnia elegans and Tagetes erecta. The area was devoid of trees. In a few areas of the grassland, landscaped areas with flowers (Zinnia elegans, Turnera ulmifolia, Hibiscus radiates, Angelonia salicariifolia) were seen which were known to be changed seasonally by the garden management.

b. Shrub: This habitat type consisted of the plant species Stachytarpheta urticaefolia, Lantana camara, Dicranopteris linearis and Syzigium species.

c. Disturbed forest: This habitat consisted of a regenerating secondary forest characterized mainly by Anacardium occidentale, Bridelia moonii, Caryota urens, Terminalia arjuna, Cassia fistula and Pueraria phaseoloides.

Two habitats were selected for the study at the Indikadamukalana Forest Reserve.

a. Undisturbed forest: Primary forest with tall trees and close canopy consisting mainly of Cinnamom umverum, Dioscorea spicata, Smilax zeylanica, Caryota urens, Thottea siliquosa and Bambusa vulgaris.

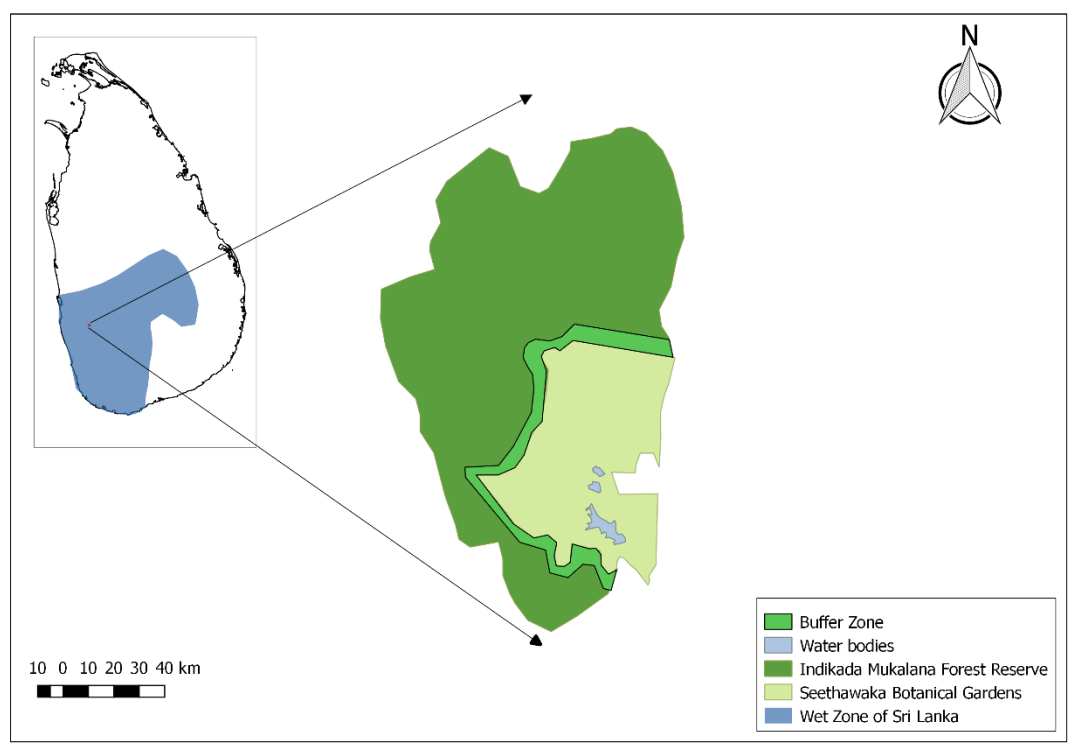

Figure 1: The study area. 


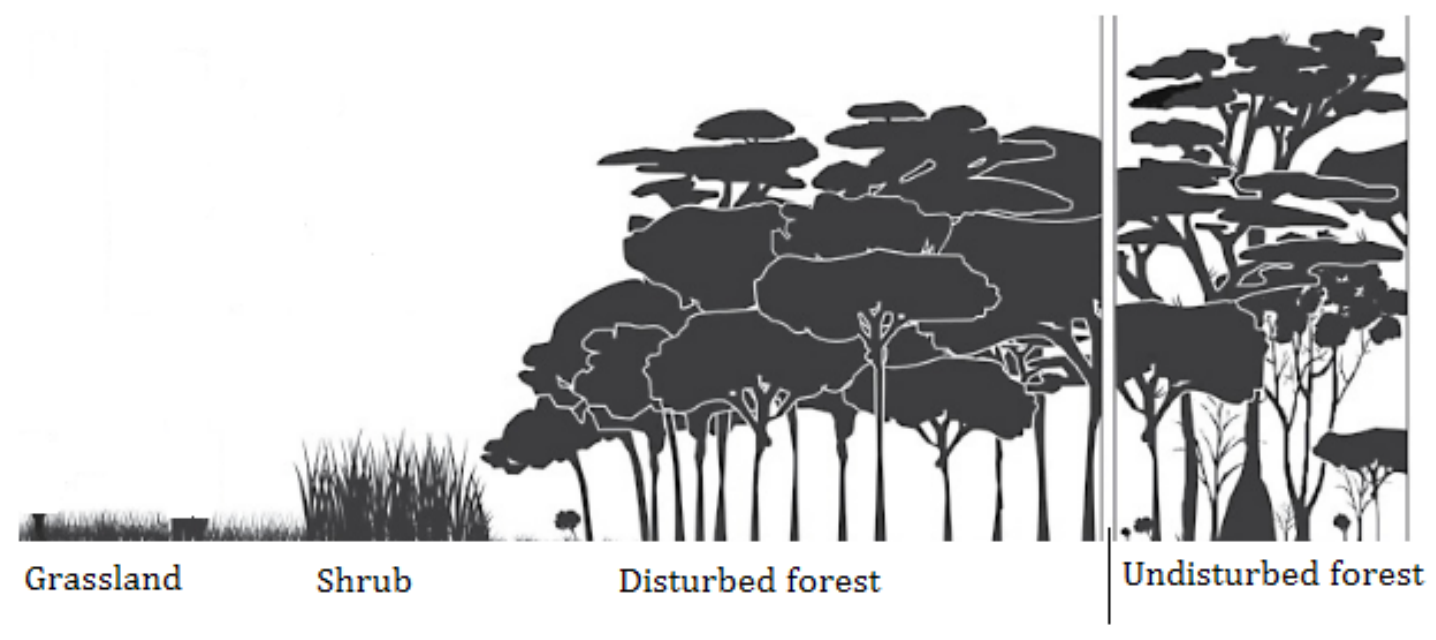

Buffer Zone

Figure 2: Habitat types sampled within the study area. (Adapted from Laborde \& Corrales-Ferrayola, 2012)

b. Buffer zone: This habitat was the area between the disturbed and undisturbed forest and consisted mainly of Trema orientalis, Desmodium heterocarpon and invasive plants such as Lantana camara, Dillenia sp. and Clidemia hirta. (Figure 2).

\section{Butterfly Sampling}

Butterflies were sampled for a period of four months from July 2016 to October 2016 using transect line method with hand netting and fruit baited traps. Each habitat type was surveyed weekly. Two $100 \mathrm{~m}$ length transects were established for each habitat type, and the butterfly species seen within a $10 \mathrm{~m} \times 10 \mathrm{~m} \times 10 \mathrm{~m}$ area were recorded. Transect surveys were carried out between 8.00 to 18.00 hours on each sampling day utilizing one hour for each transect. Additionally, fruit baited traps were placed in two sites of each habitat type and surveyed weekly 24 hours after placing the trap. Captured specimens were released after photographing (Canon Powershot SX60) and identification.

\section{Identification of Butterfly Species}

Butterfly species were identified using field guides (Jayasinghe et al., 2015) and photographs of publications (Woodhouse, 1949; d'Abrera, 1998; van der Poorten and van der Poorten, 2016).

\section{Measurement of Habitat Parameters}

During each survey climate and soil parameters of the habitat types were measured using standard equipment and methods. The climate parameters, environmental temperature $\left({ }^{\circ} \mathrm{C}\right)$, solar radiation $\left(\mathrm{w} / \mathrm{m}^{2}\right)$, relative humidity (\%) and wind speed (MPH) were measured using a portable Vantage Pro 2 weather station, and light intensity was measured using a Brannan digital luxmeter $(0.01 \mathrm{Klx})$. Rainfall measures of the sampling months were taken from the Department of Meteorology. Canopy cover was recorded using a spherical densitometer (1.04\%).

Soil temperature $\left({ }^{\circ} \mathrm{C}\right)$, soil $\mathrm{pH}$ and soil electric conductivity $(\mu \mathrm{S} / \mathrm{cm})$ were measured using standard equipment while soil moisture was measured using the gravimetric method.

\section{Data Analysis}

Species diversity of each habitat type was calculated using the Shannon-Weiner index given below.

$\mathrm{H}=\Sigma[($ pi $) \times \ln ($ pi $)]$

$\mathrm{H}=$ Shannon-Weiner Index

pi $=$ Proportion of total sample represented by species $i$.

Species evenness of habitat types were calculated using the following equation.

$\mathrm{E}=\mathrm{H} / \mathrm{H}_{\max }$

$\mathrm{E}=$ Evenness

$\mathrm{H}=$ Shannon-Weiner Index

$\mathrm{H}_{\text {max }}=\ln \mathrm{S}$

$\mathrm{S}=$ Number of Species

Climate and soil parameters of the five different habitats were compared using One-Way ANOVA of Minitab version 17.0. Tukey's pairwise comparison at $95 \%$ confidence was used to determine the significant relationships of habitat parameters between habitat types.

Species diversity and evenness of the butterflies of each habitat type were compared with the habitat parameter differences between the habitat types.

\section{RESULTS}

\section{Species Composition and Abundance of Butterflies}

A total of seventy-nine (79) butterfly species representing the families Papilionidae, Pieridae, Nymphalidae, Lycaenidae, Riodinidae and Hesperiidae were recorded from the study area (Table 1). Most of the species represented family Nymphalidae. Ypthima ceylonica was the most common butterfly encountered in family Nymphalidae. For family Papilionidae, the most common 
species was Papilio polymnestor parinda; for Pieridae, Leptosia nina nina; Lycaenidae, Jamides celeno tissama; Hesperiidae, Iambrix salsala luteipalpis. Abisara echerius prunosa the only species of Family Riodinidae in Sri Lanka was also encountered in the study.
Ceylon Rose (Pachliopta jophon) was recorded from the shrub habitat and disturbed forest of the Botanic Gardens, and buffer zone. Percentage of endemic species was high in the disturbed and undisturbed forest habitats when compared with the other habitat types (Table 2).

$39.24 \%$ of the species were endemic and the endangered

Table 1: Butterfly species recorded from different habitat types of the Seethawaka Wet Zone Botanic Gardens and Indikadamukalana Forest Reserve.

\begin{tabular}{|c|c|c|}
\hline & Species [Family within brackets] & Habitat \\
\hline 1. & *Troides darsius Gray, 1853 [Papilionidae] & Grassland habitat \\
\hline 2. & Papilio polytes romulus Cramer, 1775 [Papilionidae] & Shrub habitat \\
\hline 3. & Leptosia nina nina Fabricius, 1793 [Pieridae] & Disturbed forest \\
\hline 4. & Parantica aglea aglea Stoll, 1782 [Nymphalidae] & Undisturbed forest \\
\hline 5. & Junonia atlites atlites Linnaeus, 1763 [Nymphalidae] & Buffer zone \\
\hline 6. & Neptis hylas varmona Moore, 1872 [Nymphalidae] & \\
\hline 7. & ** Parthenos sylvia cyaneus Moore, 1877 [Nymphalidae] & \\
\hline 8. & Orsotriaena medus mandata Moore, 1857 [Nymphalidae] & \\
\hline 9. & Mycalesis perseus typhlus Fruhstorfer, 1908 [Nymphalidae] & \\
\hline 10. & ** Mycalesis patnia patnia Moore,1857 [Nymphalidae] & \\
\hline 11. & Ypthima ceylonica Hewitson, 1864 [Nymphalidae] & \\
\hline 12. & ** Jamides celeno tissama Fruhstorfer,1916 [Lycaenidae] & \\
\hline 13. & Phalanta phalantha phalantha Drury, 1773 [Nymphalidae] & Grassland habitat \\
\hline 14. & Junonia almana almana Linaeus, 1758 [Nymphalidae] & \\
\hline 15. & Zizina otis indica Murray, 1874 [Lycaenidae] & \\
\hline 16. & ** Ampittia dioscorides singa Evans, 1949 [Hesperiidae] & \\
\hline \multirow[t]{2}{*}{17.} & Junonia ipthita ipthita Cramer, 1779 [Nymphalidae] & Grassland habitat \\
\hline & & Shrub habitat \\
\hline \multirow[t]{2}{*}{18.} & Catopsilia pyranthe pyranthe Linnaeus, 1758 [Pieridae] & Grassland habitat, Shrub habitat \\
\hline & & Buffer zone \\
\hline 19. & Discolampa ethion ethion Westwood, 1851 [Lycaenidae] & Grassland habitat, Disturbed forest \\
\hline 20. & Pelopidas conjuncta narooa Moore, 1878 [Hesperiidae] & Grassland habitat, Buffer zone \\
\hline 21. & Parnara bada bada (Moore, 1878) [Hesperiidae] & \\
\hline 22. & Eurema hecabe hecabe Linnaeus, 1758 [Pieridae] & Grassland habitat, Shrub habitat \\
\hline 23. & * Potanthus satra C. \& R. Felder, 1862 [Hesperiidae] & Disturbed forest, Buffer zone \\
\hline 24. & Pelopidas agna agna Moore, 1866 [Hesperiidae] & \\
\hline 25. & Pelopidas mathias mathias Fabricius, 1798 [Hesperiidae] & \\
\hline 26. & Hypolimnas misippus Linnaeus, 1764 [Nymphalidae] & Grassland habitat \\
\hline \multirow[t]{2}{*}{27.} & Hypolimnas bolina bolina Linnaeus, 1758 [Nymphalidae] & Undisturbed forest \\
\hline & & Buffer zone \\
\hline 28. & ** Caltoris philippina seriata Moore, 1878 [Hesperiidae] & Grassland habitat \\
\hline \multirow[t]{2}{*}{29.} & Catopsilia pomona pomona Fabricius, 1775 [Pieridae] & Disturbed forest \\
\hline & & Buffer zone \\
\hline \multirow[t]{2}{*}{30.} & ** Pachliopta aristolochiae ceylonica Moore, 1881 [Papilionidae] & Grassland habitat, Disturbed forest \\
\hline & & Undisturbed forest, Buffer zone \\
\hline
\end{tabular}




\begin{tabular}{|c|c|c|}
\hline & Species [Family within brackets] & Habitat \\
\hline 31. & ** Papilio polymnestor parinda Moore, 1881 [Papilionidae] & Shrub habitat, Disturbed forest \\
\hline 32. & Graphium sarpedon teredon Felder \& Felder, 1865 [Papilionidae] & Undisturbed forest, Buffer zone \\
\hline 33. & Delias eucharis (Drury, 1773) [Pieridae] & \\
\hline 34. & ** Elymnias hypermnestra fraterna Butler, 1871 [Nymphalidae] & \\
\hline 35. & Nacaduba hermnus sidoma Fruhstorfer,1916 [Lycaenidae] & \\
\hline 36. & Abisara echerius prunosa Moore, 1879 [Riodinidae] & \\
\hline 37. & Iambrix salsala luteipalpis Plötz, 1886 [Hesperiidae] & \\
\hline 38. & Taractrocera maevius Fabricius, 1793 [Hesperiidae] & \\
\hline 39. & * Pachliopta jophon Gray, 1853 [Papilionidae] & Shrub habitat \\
\hline 40. & Graphium agamemnon menides Fruhstorfer, 1904 [Papilionidae] & Disturbed forest \\
\hline 41. & Acraea terpsicore Linnaeus, 1758 [Nymphalidae] & Buffer zone \\
\hline 42. & Mycalesis mineus polydecta Cramer, 1777 [Nymphalidae] & \\
\hline 43. & Castalius rosimon rosimon Fabricius, 1775 [Lycaenidae] & \\
\hline \multirow[t]{2}{*}{44.} & ** Cupha erymanthis placida Moore, 1881 [Nymphalidae] & Shrub habitat, Disturbed forest, \\
\hline & & Undisturbed forest \\
\hline 45. & ** Eurema blanda citrina Moore, 1881 [Pieridae] & Shrub habitat \\
\hline 46. & ** Cirroochroa thais lanka Moore,1872 [Nymphalidae] & Disturbed forest \\
\hline 47. & ** Melanitis phedima tambra Moore,1880 [Nymphalidae] & \\
\hline \multirow[t]{2}{*}{48.} & ** Cethosia nietneri nietneri C. \& R. Felder, 1867 [Nymphalidae] & Shrub habitat \\
\hline & & Undisturbed forest \\
\hline \multirow[t]{2}{*}{49.} & ** Caprona ransonnettii ransonnettii $\mathrm{R}$. Felder, 1868 [Hesperiidae] & Shrub habitat \\
\hline & & Buffer zone \\
\hline 50. & Papilio crino Fabricius, 1793 [Papilionidae] & Disturbed forest, Undisturbed forest, Buffer zone \\
\hline \multirow[t]{2}{*}{51.} & * Jamides coruscans Moore, 1877 [Lycaenidae] & Disturbed forest \\
\hline & & Undisturbed forest \\
\hline 52. & Melanitis leda leda Linnaeus, 1758 [Nymphalidae] & Disturbed forest, Buffer zone \\
\hline 53. & Prosotas nora ardates Moore, 1875 [Lycaenidae] & \\
\hline 54. & Acytolepis puspa felderi Toxopeus, 1927 [Lycaenidae] & \\
\hline 55. & ** Chilades pandava lanka Evans, 1925 [Lycaenidae] & \\
\hline 56. & Everes lacturnus lacturnus Godart, 1824 [Lycaenidae] & Undisturbed forest, Buffer zone \\
\hline 57. & * Eurema ormistoni Watkins, 1925 [Pieridae] & Disturbed forest \\
\hline 58. & * Idea iasonia Westwood, 1848 [Nymphalidae] & \\
\hline 59. & ** Euploea core asela Moore, 1877 [Nymphalidae] & \\
\hline 60. & Neptis jumbah nalanda Fruhstorfer, 1908 [Nymphalidae] & \\
\hline 61. & Zizula hylax hylax Fabricius, 1775 [Lycaenidae] & \\
\hline 62. & Megisba malaya thwaitesi Moore, 1881 [Lycaenidae] & \\
\hline 63. & ** Papilio helenus mooreanus Rothschild, 1895 [Papilionidae] & Undisturbed forest \\
\hline 64. & ** Moduza procris calidasa Moore, 1858 [Nymphalidae] & \\
\hline 65. & ** Discophora lepida ceylonica Fruhstorfer, 1911 [Nymphalidae] & \\
\hline 66. & ** Loxura atymnus arcuata Moore, 1881 [Lycaenidae] & \\
\hline 67. & * Nacaduba sinhala Ormiston, 1924 [Lycaenidae] & \\
\hline 68. & ** Jamides alecto meilichius Fruhstorfer,1916 [Lycaenidae] & \\
\hline 69. & Talicada nyseus nyseus Guérin-Méneville, 1843 [Lycaenidae] & \\
\hline 70. & Neopithecops zalmora dharma Moore, 1881 [Lycaenidae] & \\
\hline 71. & ** Tagiades litigiosa ceylonica Evans,1932 [Hesperiidae] & \\
\hline 72. & Oriens goloides Moore, 1881 [Hesperiidae] & \\
\hline
\end{tabular}




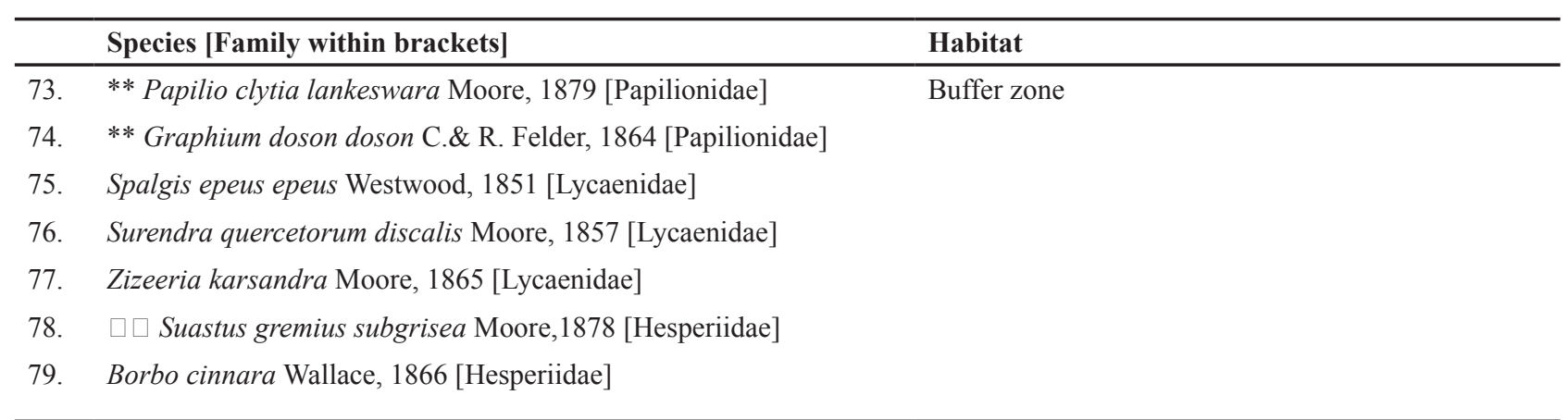

* Endemic species

** Endemic sub-species

Table 2: Number of endemic butterfly species of different habitat types as a percentage of the total number of endemic species.

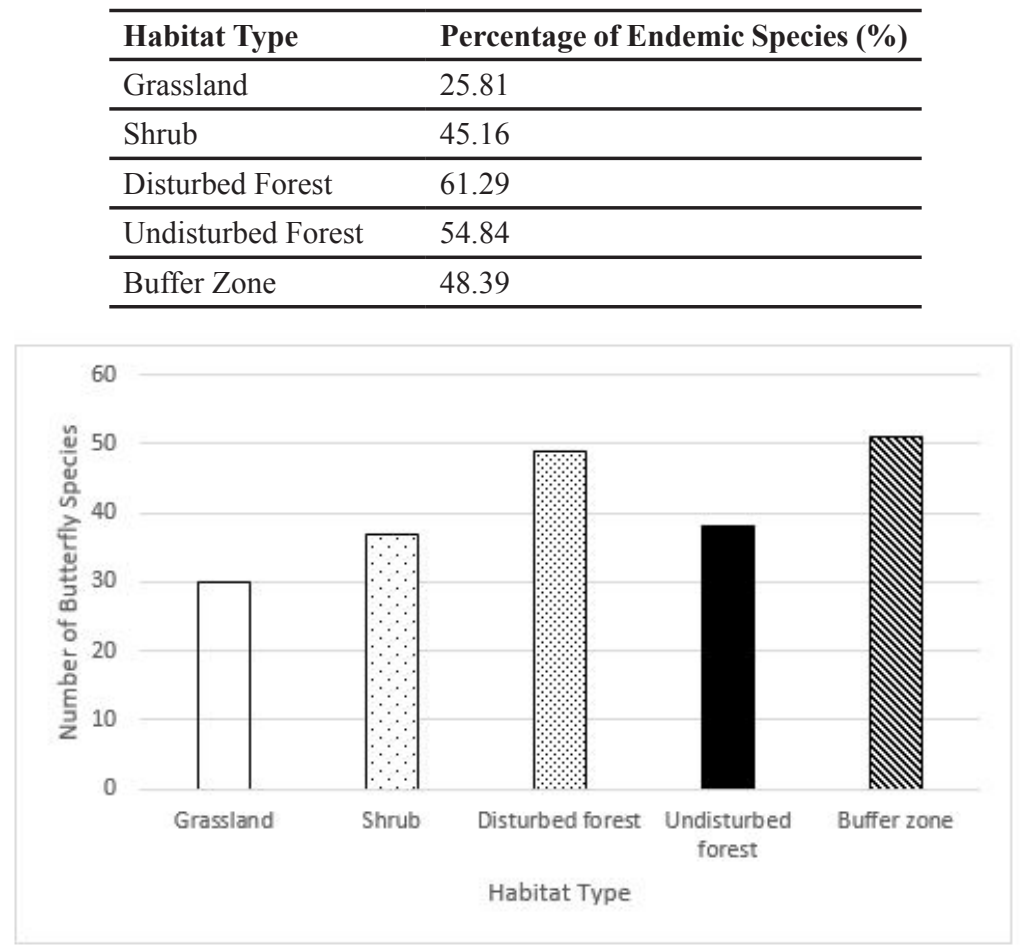

Figure 3: Species richness of butterflies in different habitat types of the Botanic Garden and Forest Reserve.

Table 3: Shannon-Weiner diversity indices and species evenness for butterfly species of the different habitat types.

\begin{tabular}{lcc}
\hline Habitat Type & Diversity Index (Mean \pm S.E.) & Species Evenness (Mean \pm S.E.) \\
\hline Grassland & $1.59^{\mathbf{A}} \pm 0.42$ & $0.71^{\mathbf{A}} \pm 0.18$ \\
\hline Shrub & $1.78^{\mathbf{B}} \pm 0.31$ & $0.77^{\mathbf{A}} \pm 0.04$ \\
\hline Disturbed Forest & $2.41^{\mathbf{B}} \pm 0.11$ & $0.78^{\mathbf{A}} \pm 0.02$ \\
\hline Undisturbed Forest & $2.07^{\mathbf{B}} \pm 0.21$ & $0.90^{\mathbf{A}} \pm 0.03$ \\
\hline Buffer Zone & $2.71^{\mathbf{B}} \pm 0.06$ & $0.88^{\mathbf{A}} \pm 0.02$ \\
\hline
\end{tabular}

Means with letters that differ along the column are significantly different.

\section{Diversity of Butterflies in Different Habitats}

The highest number of butterfly species and a significantly high diversity index was recorded for the buffer zone, the area between the Botanic Gardens and Forest Reserve. Lowest number of species and a significantly low diversity index was recorded for the grassland habitat found within the Botanic Gardens (Figure 3 and Table 3). Leptosia nina nina of family Pieridae was the most common butterfly encountered in the buffer zone habitat while Junonia atlites atlites of the same family was common in the grassland. Ypthima ceylonica of family Nymphalidae was the most common species in all other habitat types.

Species of all six butterfly families occurred in all habitat types with the exception of the grassland habitat. Family Riodinidae was not found in the grassland habitat. The species evenness of the habitat types indicated the absence of dominant butterfly species (Table 3 ). 
Table 4: Climatic and soil parameters of the habitat types at Seethawaka Wet Zone Botanic Gardens and Indikadamukalana Forest Reserve.

\begin{tabular}{|c|c|c|c|c|c|}
\hline Habitat Parameters & Grassland & Shrub Habitat & $\begin{array}{c}\text { Disturbed } \\
\text { Forest }\end{array}$ & $\begin{array}{c}\text { Undisturbed } \\
\text { Forest }\end{array}$ & Buffer Zone \\
\hline Environmental Temperature $\left({ }^{\circ} \mathrm{C}\right)$ & $29.20^{\mathbf{A}} \pm 0.36$ & $29.43^{\mathrm{A}} \pm 0.34$ & $29.36^{\mathbf{A}} \pm 0.44$ & $29.43^{\mathrm{A}} \pm 0.37$ & $29.86^{\mathbf{A}} \pm 0.39$ \\
\hline \multicolumn{6}{|l|}{ Mean \pm S.E. } \\
\hline Solar Radiation (w/m²) & $307.90^{A} \pm 58.58$ & $174.90^{\mathbf{B}} \pm 36.84$ & $181.60^{\mathbf{B}} \pm 33.95$ & $56.70^{\mathrm{C}} \pm 18.45$ & $212.20^{\mathrm{A}} \pm 32.77$ \\
\hline \multicolumn{6}{|l|}{ Mean \pm S.E. } \\
\hline Relative Humidity (\%) & $76.47^{\mathrm{A}} \pm 1.53$ & $75.73^{\mathrm{A}} \pm 1.52$ & $79.00^{\mathbf{A}} \pm 1.80$ & $77.13^{\mathrm{A}} \pm 2.16$ & $75.60^{\mathrm{A}} \pm 2.01$ \\
\hline \multicolumn{6}{|l|}{ Mean \pm S.E. } \\
\hline Wind Speed (MPH) & $3.53^{\mathrm{A}} \pm 0.58$ & $1.76^{\mathrm{B}} \pm 0.26$ & $1.33^{\mathrm{B}} \pm 0.22$ & $0.53^{\mathrm{B}} \pm 0.14$ & $1.20^{\mathrm{B}} \pm 0.21$ \\
\hline \multicolumn{6}{|l|}{ Mean \pm S.E. } \\
\hline Light intensity (Klux) & $19.91^{\mathbf{A}} \pm 3.12$ & $14.83^{\mathrm{A}} \pm 2.75$ & $15.06^{\mathbf{A}} \pm 2.61$ & $3.07^{\mathrm{B}} \pm 1.27$ & $17.98^{\mathrm{A}} \pm 2.44$ \\
\hline \multicolumn{6}{|l|}{ Mean \pm S.E. } \\
\hline Canopy Cover (\%) & $10.65^{\mathrm{A}} \pm 4.54$ & $57.10^{\mathbf{B}} \pm 3.83$ & $74.00^{\mathrm{C}} \pm 2.40$ & $86.48^{\mathbf{D}} \pm 0.72$ & $65.50^{\mathrm{E}} \pm 2.24$ \\
\hline \multicolumn{6}{|l|}{ Mean \pm S.E. } \\
\hline Soil Temperature $\left({ }^{\circ} \mathrm{C}\right)$ & $28.41^{\mathbf{A}} \pm 0.33$ & $26.15^{\mathrm{B}} \pm 0.33$ & $26.36^{\mathbf{B}} \pm 0.37$ & $25.25^{\mathrm{B}} \pm 0.26$ & $28.01^{\mathbf{A}} \pm 0.49$ \\
\hline \multicolumn{6}{|l|}{ Mean \pm S.E. } \\
\hline Soil pH & $4.59^{\mathrm{A}} \pm 0.08$ & $4.69^{\mathrm{B}} \pm 0.06$ & $5.19^{\mathrm{C}} \pm 0.07$ & $4.60^{\mathrm{A}} \pm 0.09$ & $4.94^{\mathbf{D}} \pm 0.07$ \\
\hline \multicolumn{6}{|l|}{ Mean \pm S.E. } \\
\hline Soil Electric Conductivity $(\mu \mathrm{s} / \mathrm{cm})$ & $23.01^{\mathrm{A}} \pm 2.01$ & $20.19^{\mathrm{B}} \pm 2.01$ & $22.40^{\mathrm{A}} \pm 1.50$ & $31.06^{\mathrm{C}} \pm 3.61$ & $27.24^{\mathrm{A}} \pm 3.23$ \\
\hline \multicolumn{6}{|l|}{ Mean \pm S.E. } \\
\hline Soil Moisture (\%) & $16.97^{\mathrm{A}} \pm 1.30$ & $13.03^{\mathbf{B}} \pm 0.81$ & $15.00^{\mathrm{C}} \pm 0.82$ & $14.62^{\mathrm{C}} \pm 0.89$ & $13.09^{\mathbf{B}} \pm 0.62$ \\
\hline Mean \pm S.E. & & & & & \\
\hline
\end{tabular}

Means with letters that differ along the rows are significantly different.

\section{Associations of Selected Habitat Parameters with Habitat Types}

The buffer zone and grassland habitat differed significantly in certain climatic and soil parameters. When considering the climatic parameters, wind speed of the grassland habitat was significantly high than that of the buffer zone and canopy cover was significantly low. Solar radiation did not differ between the two habitat types. When considering the soil parameters grassland habitat had a significantly low soil $\mathrm{pH}$, whereas soil moisture was significantly high. Soil temperature and soil electric conductivity did not differ between the two habitat types. Air temperature and relative humidity was more or less similar for all habitat types with no significant differences. However, significant differences were evident in the other parameters between certain habitat types (Table 4).

\section{DISCUSSION}

The establishment of botanic gardens, forest reserves and other protected areas is a strategy to avoid the loss of habitats and conserve flora and fauna. Many such areas occur in the world as a single habitat or a network of habitats where potential connectivity is possible (Alexandre et al., 2010). The Seethawaka Wet Zone Botanic Gardens and Indikadamukalana Forest Reserve of Sri Lanka are protected areas that consist of many habitat types where both structural and functional connectivity is possible.
Structural connectivity accounting for the area and spatial configuration of habitats and functional connectivity reflecting the movement of individuals or genes among populations prevents fragmentation of habitats and is essential for successful restoration and conservation management of landscapes (Tischendorf and Fahring, 2000). The current study revealed the presence of a rich butterfly fauna from the Seethawaka Wet Zone Botanic Gardens and Indikadamukalana Forest Reserve emphasizing their function towards conservation of biodiversity. Seventy-nine species of butterflies from six families were recorded from both areas which is comparatively high when considering with similar botanic gardens and forest reserves elsewhere in the world. The Experimental Botanic Gardens of Meghalaya, India with an area of 25 acres and at an altitude of $1000 \mathrm{~m}$ above sea level, houses sixty-six species of butterflies of five families (Bora et al., 2014). The botanical garden UPI in Bandung, Indonesia harbour forty species of butterflies (Sanjaya et al., 2016), while ninety-one species of butterflies under five major families occur in Royal Manas National Park of Bhutan which has an area of $1057 \mathrm{~km}^{2}$ (261,190.4 acres) (Nidup et al., 2014). The Seethawaka Wet Zone Botanic Gardens is a new botanic garden declared in 2015. However, it comprises of an array of vegetational habitats in an area of 105 acres, 100 meters above sea level. The vegetation is known to be provided by the seeds of Indikadamukalana Forest Reserve which is just adjacent to the gardens (Ranwala et al., 2017). 
The Botanic Garden has an area that is sufficient for the occupancy of butterflies when compared with other such Gardens (Bora et al., 2014; Nidup et al., 2014; Sanjaya et al., 2016) and suitable elevation. A study in Aralam Wildlife Sanctuary, Kerala revealed that butterfly species preferred habitats with low $(<250 \mathrm{~m})$ and middle $(251-$ $700 \mathrm{~m})$ elevations compared to habitats with high $(>700$ m) altitudes (Sreekumar \& Balakrishnan, 2001). Thus, the garden and forest reserve together offer an ideal refuge to a diverse community of butterfly species of the country.

Majority of butterfly species in the area was of family Nymphalidae. Diversity studies and checklists in forests (Sundufu and Dumbuya, 2008; Asela et al., 2009; Vu and $\mathrm{Vu}, 2011$ ), botanic gardens (Bora et al., 2014; Sanjaya et al., 2016), and nature reserves (Nidup et al., 2014, Koneri et al., 2017) have revealed Nymphalidae to be the most common type of butterflies found in such areas.

The buffer zone of the area harboured the highest number of butterfly species while the grassland habitat had the lowest number. A buffer zone is an extension of a protected area, or a transition zone between two different areas with limited human interference (Bhusal, 2014). In the present study the buffer zone was a transition zone between the disturbed and undisturbed forest and significantly differed in canopy cover, solar radiation, soil temperature, soil $\mathrm{pH}$ and soil moisture from that of the two habitats on either side of it. Canopy cover was low in the buffer zone than in the forest habitats paving the way to a significantly high solar radiation. The soil temperature was high leading to a significantly lower soil moisture than the soils of the forest habitats; and soil pH of the buffer zone had an intermediate value inbetween the disturbed and undisturbed forest soils. These differences in the climate and soil of the buffer zone may have given rise to a unique vegetation and microhabitats favoured by an array of butterfly species. The buffer zone consisted of many invasive plants such as Lantana camara, Dillenia suffriticosa and Clidemia hirta that were not present in the other habitat types. A study conducted in the Northern flank of Knuckle Forest Reserve of Sri Lanka showed that $56 \%$ of butterflies in the region heavily utilized Lantana camara and other invasive plants (Nisviya and Wickramasinghe, 2012). And according to Liyanagamage (2016) certain butterfly species of families Papilionidae, Nymphalidae, Pieridae and Hesperiidae show preference to Lantana camara and families Papilionidae and Nymphalidae to the invasive species Annona glabra. Thus, it is highly possible that the high species richness of butterflies in the buffer zone is associated with the presence of invasive plants in the region. Lantana camara may attract more butterflies than the other invasive species, as the flowers of the species are known to have a high nectar volume and sugar content and are usually pollinated by Lepidoptera (Carrion-Tacuriet al., 2012). Dillenia suffriticosa have flowers that are nectarless but are pollinated by insects attracted to mature fruits (Smisha et al., 2016). Clidemia hirta consists of an inflorescence bearing many nectaries and fruits borne in clusters (Rao and Sagar, 2012). Further, the high species richness of butterflies in the buffer zone could be attributed to the area being an ecotone: a zone of transition between adjacent ecological systems. In such areas increased species richness occur due to representatives of species characteristic of both of the adjacent communities described as the edge effect (Baker et al., 2002).

The grassland habitat within the Seethawaka Wet Zone Botanic Gardens had the lowest number of butterfly species and a significantly low diversity index. Further, Plum Judy (Abisara echerius), the only species of family Riodinidae of Sri Lanka found in all other habitat types was not found in the grassland habitat. A study on European butterflies have revealed that grassland area and landscape composition has an effect on the species richness of butterflies, and larger grasslands situated in landscapes consisting of a high proportion of grasslands tend to have higher butterfly species richness. Further relationships were revealed with butterfly species richness and vegetation height and abundance of flowers of grasslands, and high species richness was evident with increase of vegetation height and flower abundance (Ockinger and Smith, 2006). The present grassland situated within the Seethawaka Wet Zone Botanic Gardens was a small area amidst a mosaic of other habitat types. Further, it consisted mainly of grasses with a few grass flowers and was devoid of tall vegetation. These conditions may have led to the decrease in butterfly species richness and the unfavourable climate and soil properties of the habitat may have aggravated the situation. The canopy cover was significantly low in the grassland habitat resulting in a significantly high solar radiation and wind speed. Wind speed is known to affect butterfly behavior and density, and longer flights and moves require calm conditions (Dennis and Sparks, 2006). Increased wind speed decreased butterfly density (Kuussaari et al., 2016). The number of endemic butterfly species are also known to be effected by wind speed and endemic butterfly species significantly decreased in European grassland dominated habitats with high wind speed (Ozden and Hodgson, 2010). In the present study the lowest percentage of endemic butterfly species $(25.81 \%)$ was evident in the grassland habitat that had a significantly high wind speed when compared with the other habitat types.

In the present study the majority of endemic species of butterflies were found from the forest habitats on either side of the buffer zone. Endemic butterflies are known to be more abundant in forest habitats preferring evergreen forests (Nunez, 2012; Padhye et al., 2012); mature forests (Lewis et al., 1998), rainforests (Nunez, 2012) and cloud forests (Nunez, 2012). The disturbed forest in the Seethawaka Wet Zone Botanic Gardens and undisturbed forest in the Indikadamukalana Forest Reserve of the present study were similar in many climate and soil features but differed significantly in canopy cover, solar radiation, light intensity, soil $\mathrm{pH}$ and soil electric conductivity. The undisturbed forest had a high canopy cover leading to low solar radiation and light intensity; and the soil electric conductivity was high and soil $\mathrm{pH}$ slightly acidic. High canopy cover favours regeneration of trees but negatively effects shade-intolerant plants reducing habitat heterogeneity (Wagner et al., 2011). The endemic butterfly species may have preferred the more heterogenous disturbed forest with higher solar radiation and light intensity as was evident by the larger number 
of endemic species residing in the habitat. Soil electric conductivity is negatively correlated with soil $\mathrm{pH}$ (Aini et al., 2014). Soil properties depend on soil $\mathrm{pH}$ and affect many plant characteristics such as height, lateral spread, flower size and number and pollen production. Most plants have an optimum for $\mathrm{pH}$ ranging from 5.5 to 6.5 (Gentili et al., 2018). The low $\mathrm{pH}$ in the undisturbed forest may adversely affect plant characteristics and thus the endemic butterfly species.

The results in this study show that the Seethawaka Wet Zone Botanic Gardens and Indikadamukalana Forest Reserve are important areas of the country supporting a rich diversity of butterflies. Species of family Nymphalidae were common to the area and all habitat types. The buffer zone with many invasive plants had the highest butterfly species richness and diversity index. The grassland habitat with a significantly low canopy cover and a significantly high light intensity had a low butterfly species richness and diversity index. The study highlights the importance of the Seethawaka Wet Zone Botanic Gardens and Indikadamukalana Forest Reserve in safeguarding and conserving diversity of butterflies of the Island at a time when habitat destruction and other such factors are threatening these charismatic insects. The study enabled to highlight spatial variations in butterflies in a managed botanic garden and an adjacent undisturbed forest reserve. A future study should also focus on examining temporal variations of butterfly communities in these two locations, in relation to climatic parameters.

\section{ACKNOWLEDGEMENTS}

We are thankful to the Department of Zoology and Environment Sciences, Faculty of Science, University of Colombo for providing laboratory facilities and financial assistance for the current study.

\section{DECLARATION OF CONFLICT OF INTEREST}

The Authors declare that there is no conflict of interest.

\section{REFERENCES}

Abrahamczyk, S., Kluge, J., Gareca, Y., Reichle, S. and Kessler, M. (2011). The influence of climatic seasonality on the diversity of different tropical pollinator groups. PLoS ONE 6(11): 1-9.

Aini, I.N., Ezrin, M.H. and Aimrun, W. (2014). Relationship between soil apparent electrical conductivity and $\mathrm{pH}$ value of Jawa series in oil palm plantation. Agriculture and Agricultural Science Procedia 2: 199-206.

Alexandre, B., Crouzeilles, R. and Grelle, C.E.V. (2010). How can we estimate buffer zones of protected areas? A proposal using biological data. Brazilian Journal of Nature Conservation 8(2): 165-170.

Asela, M.D.C., Peiris, R.A.K., Priyankara, S.K.I.U., Jayasekara, R.W. and Karunarathna, D.M.S.S. (2009). Some notes on the butterflies (Lepidoptera: Papilionoidea) of Tantirimale Archaeological site, Anuradhapura district, Sri Lanka. Journal of Threatened Taxa 1(7): 392-394.

Baker, J., French, K. and Whelan, R.J. (2002). The edge effect and ecotonal species: bird communities across a natural edge in Southeastern Australia. Ecology 83(11): 3048-3059.

Bambaradeniya, C.N.B., Ekanayake, S.P., Fernando, R.H.S.S., Somaweera, R. and Perera, N. (2001). Biodiversity of the Bundala National Park and Ramsar Wetland. Proceedings of the Seventh Annual Forestry and Environment Symposium 2001 of the Department of Forestry and Environmental Science, University of Sri Jayawardenepura, Sri Lanka pp. 50.

Bambaradeniya, C.N.B., Ekanayake, S.P., Kekulandala, L.D.C.B., Samarawickrama, V.A.P., Ratnayake, N.D. and Fernando, R.H.S.S. (2002a). An assessment of the status of biodiversity in the Muthurajawela Wetland Sanctuary. Occasional Papers of IUCN Sri Lanka 3: pp.48.

Bambaradeniya, C.N.B., Ekanayake, S.P., Kekulandala, L.D.C.B., Fernando, R.H.S.S., Samarawickrama, V.A.P. and Priyadharshana, T.G.M. (2002b). An assessment of the status of biodiversity in the Maduganga Mangrove Estuary. Occasional Papers of IUCN Sri Lanka 1: pp. 49.

Bambaradeniya, C.N.B., Perera, M.S.J., Perera, W.P.N., Wickramasinghe, L.M.J., Kekulandala, L.D.C.B., Samarawickrama, V.A.P., Fernando, R.H.S.S. and Samarawickrema, V.A.M.P.K. (2003). Composition of faunal species in the Sinharaja World Heritage Site in Sri Lanka. The Sri Lanka Forester 26: 21-40.

Bhusal, N. (2014). Buffer zone management system in protected areas of Nepal. The Third Pole: Journal of Geography Education 11: 34-44.

Bora, A., Meitei, L.R. and Deb, M. (2014). Butterfly species richness and diversity in Experimental Botanic Garden, Botanical Survey of India, ERC, Umiam, Meghalaya, India. Journal of Entomology and Zoology Studies 2(5): 212-217.

d'Abrera, B. (1998). The butterflies of Ceylon. Melbourne, London: Hill House Publishers.

Carrion-Tacuri, J., Berjano, R., Guerreoro, G., Figueroa, M.E., Tye, A. and Castillo, J.M. (2012). Nectar production by invasive Lantana camaraand endemic $L$. peduncularisin the Galapagos Islands. Pacific Science 66(4): 435-445.

Dennis, R.L.H. and Sparks, T.H. (2006). When is a habitat not a habitat? Dramatic resource use changes under differing weather conditions for the butterfly Plebejusargus. Biological Conservation 129(3): 291301.

Dilts, T.E., Steele, M.O., Engler, J.D., Pelton, E.M., Jepsen, S.J., McKnight, S.J., Taylor, A.R., Fallon, C.E., Black, S.H., Cruz, E.E., Craver, D.R. and Forister, M.L. (2019). Host plants and climate structure associations of the Western Monarch Butterfly.Frontiers in Ecology and Evolution 7: 1-17.

Gentili, R., Ambrosini, R., Montagnani, C., Caronni, S. and Citterio, S. Effect of soil $\mathrm{pH}$ on the growth, reproductive investment and pollenallergenicity of Ambrosia artemisiifoliaL. Frontiers in Plant Science 9: $1-12$.

Ghazoul, J. (2002). Impact of logging on the richness and diversity of forest butterflies in a tropical dry forest in Thailand. Biodiversity and Conservation 11: 521-541. 
Jayasinghe, H.D., De Alwis, C. and Rajapakshe, S.S. (2015). A pocket guide to the butterflies of Sri Lanka. $2^{\text {nd }} E d$. Butterfly Conservation Society of Sri Lanka.

Jayasinghe, H.D., Rajapaksha, S.S. and de Alwis, C. (2014). A compilation and analysis of food plants utilization of Sri Lankan butterfly larvae (Papilionoidea). Taprobanica 6(2): 110-131.

Kerr, J.T. (2001). Butterfly species richness patterns in Canada: Energy, heterogeneity, and the potential consequences of climate change. Conservation Ecology 5(1): $1-10$.

Kitahara, M. (2004). Butterfly community composition and conservation in and around a primary woodland of Mount Fuji, central Japan. Biodiversity \& Conservation 13(5): 917-942.

Koneri, R., Saroyo and Tallei, T.E. (2017). Butterfly diversity varies across habitat types in Tangkoko Nature reserve North Sulawesi, Indonesia. Journal of Biodiversity and Environmental Sciences 10(4): 52-61.

Kuussaari, M., Rytteri, S., Heikkinen, R.K., Heliola, J. and von Bagh, P. (2016). Weather explains high annual variation in butterfly dispersal. Proceedings of the Royal Society B 283: 1-8.

Lewis, O.T., Wilson, R.J. and Harper, M.C. (1998). Endemic butterflies on Grande Comore: habitat preferences and conservation priorities. Biological Conservation 85(12): 113-121.

Liyanagamage, M. (2016). A study of the insect assemblages of two major invasive alien plant species (AnnonaglabraL. and Lantana camaraL.) in the lowland wet zone in Sri Lanka. A Dissertation submitted for the Degree of Bachelor of Science in Environment Science, Department of Zoology and Environment Sciences, University of Colombo.

Munyuli, M.B.T. (2013). Drivers of species richness and abundance of butterflies in coffee-banana agroforests in Uganda. International Journal of Biodiversity Science, Ecosystem Services \& Management 9(4): 298-310.

Myers, M.C., Mason, J.T., Hoksch, B.J., Cambardella, C.A. and Pfrimmer, J.D. (2015). Birds and butterflies respond to soil-induced habitat heterogeneity in experimental plantings of tallgrass prairie species managed as agroenergy crops in Iowa, USA. Journal of Applied Ecology 52: 1176-1187.

Nidup, T., Dorji, T. and Tshering, U. (2014). Taxon diversity of butterflies in different habitat types in Royal Manas National Park. Journal of Entomology and Zoology Studies 2(6): 292-298.

Nisviya, S.S. and Wickramasinghe, S. (2012). Diversity and distribution pattern of butterflies at Northern flank of Knuckles region, Sri Lanka. Proceedings of the International Forestry and Environment Symposium, Department of Forestry and Environmental Science, University of Sri Jayawardenepura, Sri Lanka, Pp.25.

Nunez, R. (2012). The butterflies of Turquino National Park, Sierra Maestra, Cuba (Lepidoptera, Papilionoidea). Arxius de Miscel-laniaZoologica 10: 29-49.

Ockinger, E. and Smith, H.G. (2006). Landscape composition and habitat area affects butterfly species richness in semi-natural grasslands. Oecologia 149(3): 526-234
Ozden, O. and Hodgson, D.J. (2010). Butterflies highlight the conservation value of shrubland and grassland mosaics in cypriotgariigiue ecosystems. Top Biodiversity 2010, Conference Proceedings, Intercollege Larnaca, Cyprus 67-79.

Padhye, A., Shelke, S. and Dahanukar, N. (2012). Distribution and composition of butterfly species along the latitudinal and habitat gradients of the Western Ghats of India. Checklist 8(6): 1196-1215.

Pathiraja, G.P.K.S., Perera, H.A.S.D. and Wegiriya, H.C.E. (2017). Diversity of butterflies in different habitat types in Matara district, Sri Lanka. Sri Lanka-Taiwan Joint Symposium on Advances in Entomological Research, pp.4.

Perera, M.S.J., Perera, W.P.N., Rodrigo, R.K., Ekanayake, S.P., Bambaradeniya, C.N.B., Samarawickrama, V.A.P. and Wickramasinghe, L.J.M. (2005). A biodiversity status profile of Anawilundawa Sanctuary - A Ramsar wetland in the western dry zone of Sri Lanka. Occasional Papers of IUCN Sri Lanka 9: pp. 48.

Ranwala, S.M.W., Dilrukshi, I.A.D.N., Wijesundera, D.S.A. and Attanayake, A.M.A.S. (2017). The first record on biodiversity of the natural arboretum of Seethawaka Wet Zone Botanic Gardens, Sri Lanka. The Sri Lanka Forester 38: 25-45.

Rao, R.R. and Sagar, K. (2012). Invasive alien weeds of the Western Ghats: Taxonomy and distribution. In: J.R. Bhatt (Eds), Invasive alien plants: An ecological appraisal for the Indian Subcontinent, Oxfordshire, UK: 139-161.

Samarasinghe, M.D.P., Paranagama, P. and Veediyabandara, S. (1998). Survey of the butterfly fauna of Udawalawa National Park. Proceedings of the Second Annual Forestry Symposium, University of Sri Jayawardenepura, Sri Lanka, pp.263-272.

Sanjaya, Y., Suhara and Rochmayanti, Y. (2016). Role of plant diversity to existence of butterfly in botanical garden UPI Bandung Indonesia. Journal of Entomology and Zoology Studies 4(4): 331-335.

Shields, O. (1989). World numbers of butterflies. Journal of the Lepidopterists' Society 43(3): 178-183.

Slater, C., Tolley, C., Fernando, C. and Weston, M.A. (2019). A unique Lepidoptera assemblage in primary forest and understory of central Sri Lanka. Journal of Asia-Pacific Biodiversity 12: 324-327.

Smisha, K.P., Aswani, K. and Sabu, M. (2016). Reproductive biology of Dillenias uffriticosa (Griffith) Martelli with emphasis on protandry. Bangladesh Journal of Botany 45(3): 605-611.

Sreekumar, P.G. and Balakrishnan, M. (2001). Habitat and altitude preferences of butterflies in Aralam Wildlife Sanctuary, Kerala. Tropical Ecology 42(2): 277-281.

Sundufu, A.J. and Dumbuya, R. (2008). Habitat preferences of butterflies in the Bumbuna forest, Northern Sierra Leone. Journal of Insect Science 8(64): 1-17.

Tischendorf, L. and Fahring, L. (2000). On the usage and measurement of landscape connectivity.Oikos 90: 7-19.

Van der Poorten, G.M. and Van der Poorten, N.E. (2016). The butterfly fauna of Sri Lanka. Distribution Atlas of the Butterflies of Sri Lanka and a Field Guide 1-30.

Van der Poorten, N. and Van der Poorten G.M. (2016). The 
butterfly fauna of Sri Lanka. Canada: Lepodon Books.

$\mathrm{Vu}, \mathrm{L} . \mathrm{V}$. and $\mathrm{Vu}, \mathrm{C} . \mathrm{Q}$. (2011). Diversity patterns of butterfly communities (Lepidoptera, Papilionoidae) in different habitat types in a tropical rain forest of Southern Vietnam. International Scholarly Research Network Zoology 1-8.

Vu, L.V., Bonebrake, T.C., Vu, M.Q. and Nguyen, N.T. (2015). Butterfly diversity and habitat variation in a disturbed forest in northern Vietnam. The Pan-Pacific Entomologist 91(1): 29-38.

Wagner, S., Fischer, H. and Huth, F. (2011). Canopy effects on vegetation caused by harvesting and regeneration treatments. European Journal of Forest Research 130 (1): 17-40.

Woodhouse, L.G.O. (1949). The butterfly fauna of Ceylon. $2^{\text {nd }}$ Ed. Colombo, Sri Lanka: The Colombo Apothecaries' Company Limited. 